\title{
Die 'Duisternis' as Mag in die Nuwe Testament
}

Author:
Gert J. Steyn ${ }^{1}$
Affiliation:
1Department of New
Testament Studies, University
of Pretoria, South Africa
Correspondence to:
Gert Steyn
Email:
gert.steyn@up.ac.za
Postal address:
University of Pretoria, Faculty
of Theology, Lynnwood
Road,Hatfield 0083, Pretoria,
South Africa
Dates:
Received: 04 May 2011
Accepted: 07 Aug. 2011
Published: 11 May 2012
How to cite this article:
Steyn, G.J., 2012, 'Die
"Duisternis" as Mag in
Theological Studies 68(1),
Art. \#1075, 8 pages. http://
dx.doi.org/10.4102/hts.
v68i1.1075

C 2012. The Authors. Licensee: AOSIS OpenJournals. This work is licensed under the Creative Commons Attribution License.
The purpose of this contribution is to present a general survey of darkness as power in the New Testament. It is generally accepted that darkness functions on a symbolic-metaphorical level on the one hand and on a literal level on the other hand. The former receives attention in this study where darkness is almost exclusively connected with the domain of power of the evil. The issue of darkness is investigated from four dimensions (1) as an opposing power to light in a dualistic worldview, (2) as a ruling power with a grip on death and the grave, (3) as a power of the evil and the struggle for liberation and (4) as a symbol and instrument of judgement of God in an apocalyptic worldview, with darkness eventually becoming the condemned. It is concluded that there seems to be at least two New Testament perceptions regarding the position of darkness as power: The domain of evil's darkness is located in the 'underworld', but gradually this view changed to also include a space in the layers of heaven above the earth. Earthlings found themselves in the midst of the struggle between Belial and Christ - the latter who finally conquers the power of darkness and now rules above the dark forces of evil.

\section{Inleiding}

Die antieke wêreld was 'n wêreld sonder elektrisiteit. Dit is vanselfsprekend dat die effek en die impak van duisternis dus veel meer dramaties sou wees as wat vandag die geval is. Olielampies en fakkels moes die nag se duisternis verdring totdat die son weer die volgende oggend sy verskyning maak. Mense was bang vir die duisternis waarin roofdiere en rowers geskuil het. Dit was die domein van die onbekende, die dooies en die demoniese. Dit is dus geensins vreemd dat die duisternis simbool geword het van die onbekende, van gevaar en van die bose nie. Anderkant die grense van lig is dit wat nie gesien kan word nie. Hier hoort die graf en die dood tuis en in hierdie 'buitenste duisternis' word die kosmiese mag van die bose se heerskappy gevind. Maar as die duisternis die domein van die bose en die onbekende is, is God se domein een van lig. Hy regeer op 'n troon van glans en stralende glorie. Hyself is 'n verblindende lig waarna 'niemand kan kyk en bly lewe nie'. Hy is die Lig. Hy kom as geïnkarneerde Logos, as 'n lig in die duisternis van die wêreld. So is daar dan voortdurend 'n stryd tussen lig en duisternis, tussen dag en nag.

Hierdie bydrae het ten doel om 'n oorsigtelike beeld te bied van duisternis as mag in die Nuwe Testament (NT). Die intensie is nie om volledig te wees nie, maar eerder om oriënterend te wees en 'n verteenwoordigende snit aan te bied van die NT se verstaan van duisternis as mag. Die term бкóto [duisternis] kom 31 keer in die NT voor ${ }^{1}$ en dieselfde woordgroep 'n verdere 27 keer. ${ }^{2}$ Daar word algemeen aanvaar dat dit hoofsaaklik op twee vlakke in die NT funksioneer en feitlik deurgaans in direkte kontras met lig staan: enersyds op 'n metaforiese en simboliese vlak (feitlik uitsluitlik verbind met die magsdomein van die bose) en andersyds op 'n letterlike vlak. ${ }^{3}$ Dikwels is selfs die gebruik van duisternis op 'n letterlike vlak swaar gelade met simboliese betekenis binne die teologiese konteks van die NT skrywers. ${ }^{4}$ Hierdie bydrae wil dan veral fokus op die simbolies-metaforiese gebruik van duisternis wat in vier dele bespreek sal word:

- Duisternis as mag in 'n dualistiese wêreldbeeld.

- Duisternis as mag van die dood en die graf.

- Duisternis as mag van die bose en die stryd om bevryding.

- Duisternis as simbool van oordeel in 'n apokaliptiese wêreld.

1.Mattheus 4:16; $6: 23$ (2 keer); $8: 12 ; 22: 13 ; 25: 30 ; 27: 45 ;$ Markus 15:33; Lukas 1:79; $11: 35 ; 22: 53$; 23:44; Johannes $3: 19 ;$ Handelinge 2:20; 13:11; 26:18; Romeine 2:19; 13:12; 1 Korintiërs 4:5; 2 Korintiërs 4:6; 6:14; Efesiërs 5:8, 11; 6:12; Kolossense 1:13; 1 Tessalonisense 5:4, 5; 1 Petrus 2:9; 2 Petrus 2:17; 1 Johannes 1:6; Judas 13 (Bachmann \& Slaby 1980:1707-1708).

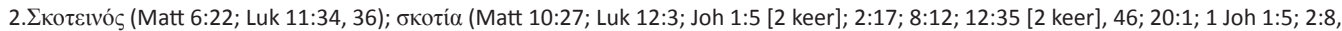

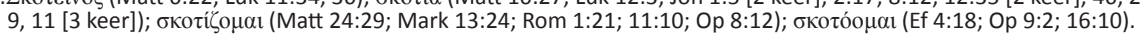

3.Louw en Nida (1988b:224) onderskei ook twee betekenismoontlikhede: 'darkness' en 'evil world'.

4.Onderskeid moet egter hier getref word tussen die terme 'nag' (wat oorwegend letterlik in die NT gebruik word) en 'duisternis' (wat oorwegend simbolies in die NT gebruik word). 


\section{Duisternis as mag in 'n dualistiese wêreldbeeld}

\section{Zoroastrianisme en duisternis}

Die Joods-apokaliptiese verstaan van twee opponerende kosmiese magte vind waarskynlik sy oorsprong in die Zoroastrianistiese (Persiese) denkwêreld. ${ }^{5}$ Hiervolgens was daar 'n dualistiese geesteswêreld (Reese 1992:140) met Ahura-Mazda (of Ormuzd), 'n goeie en wyse god en 'n god van lig. Hy was die aanvoerder van die geeste van die lig. Teenoor hierdie goeie mag het Angra-Mainhu (of Ahriman) as ' $n$ bose god van die kwaad en van die duisternis gestaan. Hy was die aanvoerder van die duister koninkryk van demone. Zoroastrianisme het geglo dat hierdie twee magte van goed en kwaad oorspronklike, onafhanklike en gelyke magte was - elk verhewe in sy eie domein. Die aarde, geskep deur die goeie god Ormuzd, het die slagveld van hierdie twee magte geword (Rutherford 1930:1241).

\section{Dooie Seerolle - Gemeenskap en duisternis}

Die gemeenskap(pe) van die Dooie Seerolle (Qumran) het 'die geeste van Duisternis', 'engel van die duisternis' en die 'kinders van die duisternis' gekontrasteer met 'geeste van Lig', 'die engel van die lig' en die 'kinders van die lig' (1QS 3:17-4:1; kyk ook 4:11-14.). ${ }^{6}$ Die siening dat God twee Geeste sou geskep het, 'n Gees van Lig en 'n Gees van Duisternis (1QS 1:18-24; T. Jud. 20:1-5; Jn 14:17; 15:26; 16:13; 1 Jn 4:6), was moontlik oorgeneem van die Zoroastrianistiese dualisme. ${ }^{7}$ Daar was geglo dat hierdie magte deur die geskiedenis met mekaar meeding en dat die mensdom in navolging van die een of die ander kan leef. Die 'Prins van Lig' beheer die lewens van die 'kinders van geregtigheid', terwyl die 'Engel van Duisternis' heerskappy voer oor die 'kinders van ongeregtigheid' (1QS 3:17-4:1; 4:2-11; 1QM 13:9-12; Elgvin 2000). Beide Geeste streef dan vir heerskappy oor die hart van die individu (1QS 4:23-26; T. Asher 1:3-5) en soms word die 'kinders van geregtigheid' verlei deur die 'Engel van Duisternis' (1QS 3:22; Elgvin 2000). Vanuit 'n apokaliptiese toekomsverwagting is daar voorts geglo (in onder meer die Oorlogsrol, 1QM) dat God 'n einde sou maak aan die bose magte (kyk ook 1QS 4:18-19) en dat die 'kinders van die duisternis' uiteindelik triomfanklik oorwin sou word (1QM 1:14; 6:6; 11:4, 9; 13:13-14). ${ }^{8}$ Nie net sou die oorwinning plaasvind op die fisiese slagveld nie, maar die stryd sou selfs tot in die hemele gevoer word teen die bonatuurlike magte van die bose (Arnold 1992:444). Die Oorlogsrol (1QM) beskryf hierdie finale stryd tussen die twee magte wat op die vlak van

5.Versigtigheid moet egter hier gehandhaaf word. Vergelyk Conzelmann (1964:423-445): 'Persian ideas have influenced this. But one may ask whether light and darkness have also been borrowed from these as a mode of expression or whether a development is to be assumed within Judaism itself.'

6.Vermes (1987:65) formuleer aan die hand van hierdie passasie, God 'loves the one everlastingly ... but the counsel of the other He loathes and for ever hates its ways.

7.'n Eenvoudige oorname van kosmiese dualisme is egter nie hier ter sprake nie. Abegg (2000) wys daarop dat 'Although this appears at first glance to be a cosmic dualism, it becomes clear that the real intent is ethical, as light and darkness are best understood as metaphors for righteousness and wickedness: "[the Sons of Rigteousness shall shine to all the ends of the world]" (1QM 1:8)'.

8. It describes in some detail a war at the end of time between the "Children of Light" 8. It describes in some detail a war at the end of time between the "Children of Light"
and the "Children of Darkness," a war whose individual battles are at times lost to and the "Children of Darkness," a war whose individual battles are at times lost to
the forces of evil but whose final victorious outcome is never in question' (Abegg 2000) mens en engel gevoer word. Hiervolgens sou die aartsengel Michael die Kinders van die Lig in die stryd aanvoer, terwyl Belial weer die leier van die Kinders van die Duisternis sou wees (Abegg 2000).

\section{Dualistiese trekke in die Lukaanse geskrifte}

Dit wil voorkom asof Lukas moontlik by twee gebeure aansluit by 'n soort dualistiese wêreldbeeld. Enersyds in sy verstaan en beskrywing van Christus se koms, en andersyds in sy interpretasie van die bekering van Paulus en die gepaardgaande opdrag aan hom. In hierdie twee persone se bediening op aarde word God se ligstryd teen die duisternis van die bose aangesê. Hiervoor steun Lukas hoofsaaklik op die taal en die beelde van Jesaja. ${ }^{9}$

\section{Christus bring lig in die duisternis}

In Sagaria se loflied (Benedictus) word vermeld van die 'verlossing deur vergifnis van sondes' wat Christus sal bring (Luk 1:77). Hy sal 'soos die môreson opgaan en uit die hoogte op ons afstraal, om lig te bring aan die wat in duisternis en in die skaduwee van die dood lewe ${ }^{\prime 10}$ (Luk 1:78-79). Hierdie beeld is ' $n$ sinspeling op Psalm 106:10 (LXX), Jesaja 42:7 en veral Jesaja 9:1 (LXX) (Fitzmyer 1981:388; Marshall 1978:95; Evans 1992:586). Die metafoor van lig as redding is nie onbekend aan Lukas nie (Mallen 2008:90) en kom weer na vore in Lukas 2:30-3211 wanneer ook Simeon in sy lofsang (Nunc dimittis) dieselfde punt maak:

... omdat my oё $\mathrm{U}$ verlossing gesien het wat $\mathrm{U}$ gereedgemaak het voor die oë van al die volke: 'n lig tot verligting van die nasies en tot eer van u volk Israel. (Luk 2:30-32)

Met Jesus se gevangeneming, berig die Lukaanse Jesus dat

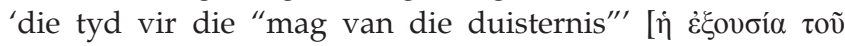
бкótovৎ] nou daar is en dat diegene wat Hom gevange neem, nou hulle kans daartoe het (Luk 22:53). In hierdie stryd tussen die mag van die Lig en die mag van die Duisternis, laat God 'n oomblik toe vir 'n tyd van duisternis. Die simboliese tydelike oorwinning van die Duisternis as mag van die Bose oor die mag van die Lig van Christus vind plaas wanneer Christus aan die kruis sterf en duisternis vir drie ure lank in die middel van die dag op die aarde toesak (Luk 23:44; Mark 15:33; Matt 27:45). In hierdie moment word Christus se lig tydelik uitgedoof en verdring die mag van die duisternis Christus as die Lig. Hiermee word die duisternis dan ook 'n swaar gelade apokaliptiese voorteken van God se ontrekking en komende oordeel oor die wêreld.

\section{Paulus se opdrag}

In Handelinge 13:47, tydens sy Antiocheense toespraak, herhaal die Lukaanse Paulus die opdrag wat hy tydens sy

9.Vergelyk Mallen (2008:100): "Luke often expresses the language and images of (Christian) salvation in a manner that echoes the salvation language of Isaiah.'

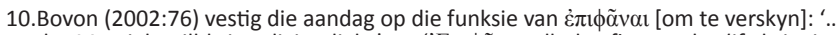
the Messiah will bring divine light' en 'E $\pi$ ı $\tilde{\alpha}^{2} \alpha_{\mathrm{l}}$ alludes first to the life-bringing light'.

11.Mallen (2008:123) dui oortuigend aan hoedat Lukas se narratief hier die 'plot' van Jesaja 40-55 resoneer. Twee belangrike elemente sluit onder meer in (1) dat God sy volk deur 'n Nuwe Eksodus sal lei, vanaf Babilon terug na Jerusalem (Jes God sy volk deur 'n Nuwe Eksodus sal lei, vanaf Babilon terug na Jerusalem (Jes
40:3-11); en (2) dat deel van die volk se roeping - aangewys as dienaar Jakob of Israel - is om God se lig en oordeel aan die nasies te bring (Jes 42:1-6). 
bekering ontvang het by wyse van ' $n$ aanhaling uit Jesaja 49:6:12 'Ek het U gegee as 'n lig vir die nasies, sodat $U$ verlossing kan bring tot in die uithoeke van die aarde' (Hand 13:47).

Tydens Paulus se berig oor sy bekering voor Agrippa, meld hy weer sy opdrag in Handelinge:

Jy moet hulle oë oopmaak sodat hulle hulle van die duisternis tot die lig en van die mag van die Satan tot God kan bekeer. Deur in My te glo, sal hulle sondes vergewe word en sal hulle deel word van die volk van God. (Hand 26:18)

Barrett het reeds gewys op die ooreenkoms hier tussen Lukas en die Dooie Seerolle. ${ }^{13}$ So dui lig dan op God en duisternis op Satan. Terwyl die vermoë om te sien (vanweë die lig) onderwerping aan die mag van God veronderstel, dui die onvermoë om te sien (vanweë die duisternis) op die mag van Satan. Volgens Lukas ontvang Paulus dan - in laasgenoemde se woorde - die opdrag om heidene 'van die duisternis tot die lig $^{14}$ en van die mag van die Satan tot God'; ${ }^{\prime 15}$ te bekeer. ${ }^{16}$ Daar is ' $n$ sterk sinspeling op Jesaja 42:6-7, $16^{17}$ (een van die 'Kneg van die Here' gedeeltes), ${ }^{18}$ asook op Jesaja 49:6, 9. ${ }^{19}$ Die aanbreek van redding by wyse van 'n omdraai van duisternis na lig, is 'n metafoor wat prominent in Jesaja teruggevind kan word (vgl. Jes 8:23;20 9:1;21 60:1-322).

\section{Johannese voorstelling}

Veral by Johannes word ' $n$ dualisme van simboliese lig en duisternis gevind (vgl. Joh 3:2; 11:10) (Osborne 1992:684) (33 $^{23}$

12.Vergelyk Mallen (2008:90): 'The mission of the servant to bring God's light to the nations (Isa. 49.6) forms the background of both these passages.'

13.Barrett (2004:1161) verwys spesifiek na 1QS 11:7f. en sê voorts: 'The image of light and darkness, and Satan and Belial, also occurs in the Qumran literature.

14.Schneider (1982:374) wys in hierdie verband ook op die volgende: 1 Tessalonisense 5:4f; 2 Korintiërs 4:6; Kolossense 1:13; Efesiërs 5:8; 1 Petrus 2:9 - in noue aansluiting by Jesaja 42:7, 16 .

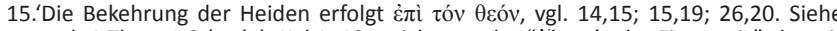

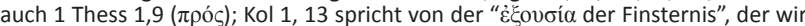
entrissen wurden' (Schneider 1982:374).

16.Pesch (1986:278) betrek hier die rol van die doop in Handelinge: 'In der Taufe in der sie "Nachlaß der Sünden empfangen" (vgl. 10,43), werden sie dem Machtbereich Satans entrissen, da sie sich "zu Gott" (vgl. 14,15; 15,19; 26,20) hingewandt haben.'

17.'Ek maak jou my verbond met my volk, my lig vir die nasies. Jy sal blindes laat sien, jy sal gevangenes uit die tronk bevry; wie in die donkerte van die gevangenis sit, sal jy laat uitgaan' 'Ek laat die blindes loop op 'n pad wat hulle nie ken nie ..., Ek verander die donker voor hulle in lig ..." (Jes 42:6-7, 16).

18.Mallen (2008:90): 'This task of opening blind eyes is particularly associated with

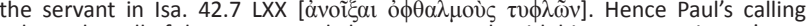
echoes the call of the servant and also corresponds with his own experience.

19.'Ek maak jou 'n lig vir die nasies sodat die redding wat Ek bewerk, die uithoeke van die aarde sal bereik' '... om aan die wat gevange gehou word, te sê: "Gaan uit!", aan die wat in die donker opgesluit sit: "Kom uit!"” (Jes 49:6).

20.'Maar in die land waar daar duisternis is, sal daar nie langer donkerte wees nie' (Jes 8:23)

21.'Die volk wat in duisternis woon, het 'n groot lig gesien, oor die wat in die donker land was, het 'n lig geskyn' (Jes 9:1).

22.'Kom, Jerusalem, laat skyn jou lig! Vir jou het die lig gekom, die magtige teenwoordigheid van die Here het vir jou lig gebring. Daar is donkerte oor die aarde, duisternis oor die nasies, maar vir jou gee die Here lig, oor jou verskyn sy magtige teenwoordigheid. Nasies kom na jou lig toe en konings na die glans van die nuwe dag wat vir jou aangebreek het' (Jes 60:1-3).

23.Osborne (1992:408) sluit verkeerdelik Johannes 13:20 in. Indien die bedoeling Johannes 13:30 sou wees, is dit steeds ' $n$ foutiewe verwysing aangesien die term daar 'nag' (vv́ $\xi$ ) is. Vroeër het Williams (1992) die simboliese waarde hiervan vermeld toe hy berig het "John was using "night" symbolically. Judas had surrendered himself to the power of darkness'. Die terme vir 'lig' en 'duisternis' surrendered himself to the power of darkness'. Die terme vir 'lig' en 'duisternis'
kom egter slegs voor in Johannes 1-12. Die enigste uitsondering is Johannes 20:1 kom egter slegs voor in Johannes 1-12. Die enigste uitsonderin
wanneer Maria 'vroeg, terwyl dit donker was' na die graf gaan. waar duisternis teenoor lig gekontrasteer word (Joh 1:4-5; 3:19; 12:35-36; kyk ook 1 Joh 1:5-6; Metso 2000). Hierdie dualisme is volgens sommiges primêr soteriologies van aard..$^{24}$ Binne 'n hoofsaaklik vertikale dualisme (Ladd 1974:223), word die 'wêreld van bo' (die sfeer waarvandaan die engele kom en weer opvaar - vgl. Joh 1:51; 3:13, 31) onderskei van die 'wêreld van onder' (Joh 8:23). Laasgenoemde is beperk (Joh 6:51, 58, 63; 4:13) en word beheer deur die 'wêreld van bo' $(1: 11 ; 6: 38-40,51 ; 17: 6-10)$. Hulle haat die 'wêreld van bo' (Joh 7:7) en verwerp die inkarnasie van Jesus Christus. Sodoende word hierdie twee wêrelde dan verteenwoordig deur twee opponerende magte: enersyds is Christus, die Logos (Joh 1:14), 'die Lig vir die wêreld' (Joh 1:4-10; 8:12; 9:5;

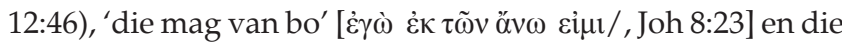
openbaring van God die Vader; andersyds is 'die heerser van

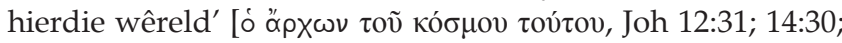

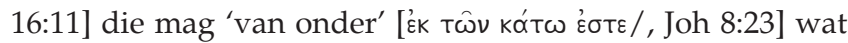
die wêreld deur sonde verslaaf, sodat dit God teenstaan deur nie die inkarnasie van sy Seun te aanvaar nie (Joh 7:7; 15:18) (Du Rand 1997:25). Die wêreld bevind haarself dus in 'n sfeer van duisternis (Joh 8:12; 1 Joh 2:8) en om in die duisternis te lewe is om nie te weet waar jy gaan uitkom nie (Joh 12:35; 1 Joh 2:11).

Die Johannese lig-duisternis dualisme neem 'n etiese dimensie aan deur die handelinge van mense wat in die lig van die 'nuwe gebod' gesien kan word. In Jesus en in die ontvangers van die eerste Johannesbrief is die duisternis aan die verbygaan en 'skyn die ware lig' reeds (1 Joh 2:8). ${ }^{25}$ Maar 'n lewenstyl waarin beweer word dat persone aan Christus deel het, en tog 'in duisternis lewe,' is 'n leuen en handel nie volgens die waarheid nie (1 Joh 1:6). Dieselfde geld vir iemand wat beweer dat hy in die lig is, maar sy broer haat: so 'n iemand is steeds 'in die duisternis', 'lewe in die duisternis en weet nie waar hy gaan uitkom nie, omdat die duisternis hom blind gemaak het' (1 Joh 2:9, 11). Volgens Johannes 3:19 kom die 'skeiding' dus so: 'die lig het na die wêreld toe gekom, en tog het die mense eerder die duisternis as die lig liefgehad, want hulle dade was sleg'. Omdat God lig is en daar geen duisternis in Hom is nie (1 Joh 1:5), is ook Christus die ware lig wat elke mens verlig (Joh 1:9). Hy is die Lig wat in die duisternis skyn (1 Joh 2:8) en die duisternis kon dit nie uitdoof nie (Joh 1:5). Hy 'is die lig vir die wêreld en wie Hom volg, sal nooit in die duisternis lewe nie, maar sal die lig hê wat lewe gee' (Joh 8:12). Die wat in hierdie Lig glo, sal nie in die duisternis bly nie (12:46). Die idee dat God die Gewer van lig is, word reeds in die Ou Testament (OT) gevind op plekke soos Deuteronomium 33:2 ('Hy laat van Seïr af sy lig oor sy volk skyn') en Psalm 118:27 ('God is die Here wat vir ons lig gewys het'), terwyl die gedagte van 'n 'land waar daar duisternis is, maar waar nie langer donkerte sal wees nie' reeds gevind kan word - via Mattheus 4:16 - in Jesaja 8:23 en 9:1.

24.So ook geïmpliseer deur Hatina (2000:348-351): “John presents Jesus as a preexistent messianic figure who comes to rescue his people from this world of darkness, hostility and sin.

25.In hierdie verband het Paulus reeds in Romeine 13:12 ' $n$ oproep gedoen dat 'die

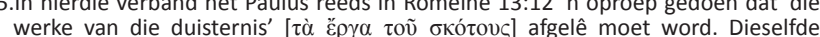

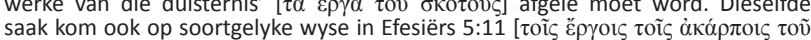

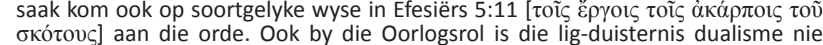
$\sigma \kappa o ́ \tau o v \zeta]$ aan die orde. Ook by die Oorlogsrol is die lig-duisternis dualisme
kosmies van aard nie, maar is die bedoeling eties van aard (vgl. Abegg 2000). 
Johannes se etiese en eskatologiese dualisme toon interessante ooreenkomste met die Dooie Seerolle se dualistiese taal en die leer oor die twee geeste:

God created man to rule the world, and he assigned two spirits to him that he might walk by them until the appointed time of his visitation; they are the spirits of truth and of injustice. From a spring of light come the generations of truth, and from a well of darkness the generations of injustice. Control over all the sons of righteousness lies in the hand of the prince of lights, and they walk in the ways of light; complete control over the sons of injustice lies in the hand of the angel of darkness, and they walk in the ways of darkness. (1QS 3:17-21 - vertaling M.A. Knibb) ${ }^{26}$

Johannes se Jesus stel dit onomwonde aan Andreas en Filippus dat, terwyl hulle nog die lig by hulle het, hulle in

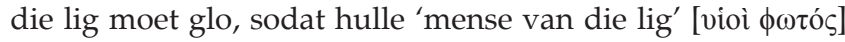
kan wees (Joh 12:36). Johannese geleerdes maan egter dat die Johannese dualisme nie verwar moet word met Griekse kosmiese dualisme of met dié van Qumran nie (Du Rand 1997:25; Barrett 1982:101). ${ }^{27}$

\section{Duisternis as mag van die dood en die graf}

Sheol, die ou Hebreeuse konsep van die plek van die dood, was 'n reuse ondergrondse plek van duisternis (Job 10:21-22; Ps 88:12; Ps 143:3; vgl. Orr 1930b:2761), donkerte en stof. ${ }^{28}$ Dit was die bestemming van almal wat sterf en stem grootliks ooreen met die Griekse onderwêreld van die god Hades (Bauckham 1992:14). Duisternis was die sleuteleienskap van die onderwêreld (Kittel, Friedrich \& Bromiley 1985:1049; Held 1973:179; Lewis 1992:103) ${ }^{29}$ en dit was in elke opsig anders as die wêreld van die lewendes (Job 28:13; Spr 15:24; Eseg 26:20; 32:23; Hen 103:7). Dit is 'n plek van verval (Job 26:6; 28:22; 31:12; Ps 88:11; Spr 27:20) en 'n 'land van die donker nag met sy diep duisternis waar niks georden is nie, waar die lig self donker is' (Job 10:22), 'n plek waar God en mens nie meer gesien kan word nie (Jes 38:11) en waar God nie meer geprys en gedank word nie (Ps 6:5; 115:17), waar sy kwaliteite nie meer erken word nie en daar nie meer oor sy wonders nagedink word nie (Ps 88:10-13; Jes 38:18-19). Hier weet die dooies niks en is self ook vergete, hulle ervaar nie emosies van liefde, haat of hartstog nie; hier werk hulle nie en is daar geen insig, kennis of wysheid nie (Pred 9:5, 6, 10) (Luering 1930:815). In Hiskia se lied is daar sprake van die 'poorte van die doderyk' (Jes 38:10), terwyl ander gedeeltes verwys na die 'poorte van die dood' (Ps 9:14; Job 38:17) of die 'poorte van die doodskaduwee' (Job 38:17) en na die 'grendels van die doderyk' (Job 17:16) (Jeremias 1964:924).

Die diepste afgrond en gruwelikste deel van die onderwêreld was volgens die Grieke en Romeine Tartarus (of Erebos) gewees, 'n plek van ewige duisternis en waar die skuldiges

26.Kyk ook 10S 3:13-4:26 (Metso 2000).

27.Barrett (1982:101) meen: 'The mere use of images in pairs, such as light and darkness, or even matter and spirit, is not in itself dualistic.

28.Martin-Achard (1992:680) wys daarop dat "to return to the dust" means to die [Gen 3:19; Pss 90:3; 104:29] and the "dwellers of the dust" are none other than the dead [Dan 12:2; Job 20:11])'.

29. If light means potentiality, going into the dark means death. The realm of the dead is a dark realm' (Kittel, Friedrich \& Bromiley 1985:1049). hulle straf moes uitdien (Grant \& Hazel 1979:155; Willis 1993:146). Hades was die broer van Zeus, die $\operatorname{god}^{30}$ van die dooies en heerser oor die onderwêreld waar hy oor sy koninkryk van duisternis geheers het (Souli 1998:55). Hy was hard en ongenaakbaar en het niemand toegelaat om na die land van die lewendes terug te keer nie. Hades se naam was as ongelukkig beskou en so min as moontlik gebruik. Dikwels is daar dan met eufemistiese beskrywings na Hades

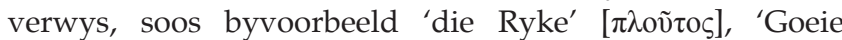

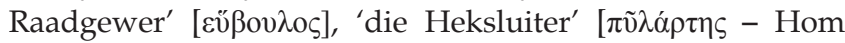

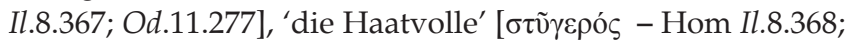

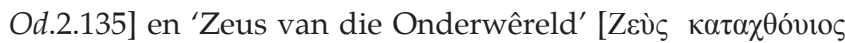
- Hom Il 9.457] (Grant \& Hazel 1979:155). Ten spyte van Hades se ongenaakbaarheid het die Grieke en Romeine nie aan Hades gedink as boos, satanies of onregverdig nie. Sy 'huis' was in geen opsig 'n hel nie, hoewel dit 'n kerker was en Hades self ' $n$ tronkbewaarder - dikwels uitgebeeld met 'n sleutel in sy hand (Grant \& Hazel 1979:155). In sy duisternisryk bestaan die skadufigure van afgestorwenes sonder doel en sonder kommunikasie (Grant \& Hazel 1979:155; Martin-Achard 1992:680). ${ }^{31}$ Dis dan ook die plek waar Zeus die Titane, Chronos en sy broers, opgesluit hou (Van Reeth 1994:241). Hulle is ná die Titaanse stryd met kettings gebind en in Tartarus gegooi waar die 'HonderdHand Reuse' oor hulle wag hou (Souli 1998:13).

Ook in die NT is Tartarus die plek waar engele wat gesondig het geboeid sit en waar hulle in die 'kloof van duisternis'

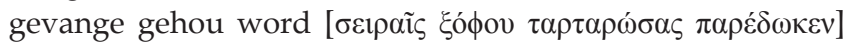
vir die oordeel (2 Pet 2:4). Die Judasbrief vermeld dat die engele wat hier met 'onbreekbare kettings gebind is' en wat

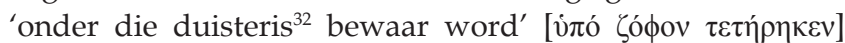
vir die 'oordeel van die groot dag', daardie engele is wat

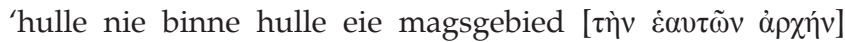

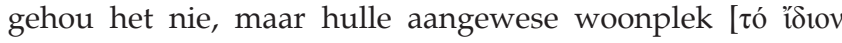

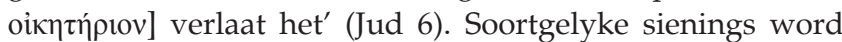
gehuldig in sommige van die Joods-apokaliptiese literatuur, te wete in $\operatorname{Henog}^{33}$ en Jubilees, asook in die apokriewe geskrif Barug - waarskynlik na aanleiding van Genesis 6:1-4 (Elgvin 2000:153; Orr 1930a:1371). In hierdie plek van 'duister

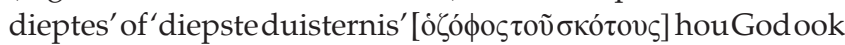
vir die dwaalleraars plek gereed waar hulle ewig salbly (Jud 13; 2 Pet 2:17). ${ }^{34}$ Teologies impliseer dit God se beheer van hierdie magte en dui op hulle finale en uitermatige verwoesting. Dit impliseer die beperkende mag van die duisternisryk volgens

30.Die naam 'Hades' verwys tereg na die god en nie na sy magsdomein nie. Die idee dat Hades na die plek verwys kom waarskynlik van ' $n$ verkeerde verstaan van die datliptiese Grieks ple elliptiese Griekse was (Willis 1993:146). Slegs in 1 Korintiërs 15:55 beteken hades 'graf' (Steyn 2008:442-443).

31 .... generally pursuing the activities of their former life in a wan, mechanical fashion. Their habitation (called the 'Plain of Asphodel') was dreary and offered no variety or social intercourse' (Grant \& Hazel 1979:155).

32.Die NAV (1983) vertaal 'in duister dieptes'.

33.'Such is the case with the realm of the dead, the prisons for the wayward angels and stars, and the location of the tree of life and tree of wisdom in the Book of the Watchers: the reader is offered a guarantee that these places really exist (Enoch Watchers: the reader is offered a guarantee that these places really exist (Enoch has seen them!)' (Bautch 2006:262). Kyk ook Nickelsburg (1992:585): 'Constitutive in the judgment will be a resurrection of the dead $(51 ; 61: 1-5)$, after which the righteous and chosen will dwell on a newly created earth, from which the sinners 58; 54; 63).'

$34 . .$. the dark, gloomy nature of hell as a place of punishment' (Louw \& Nida 1988a:7). 
die Joods-Christelike verstaan - 'n siening waarvan ook Job 38-41 berig. Hiervolgens blyk dit dat die mag van Jahwe selfs reik tot by die gesimboliseerde gees van die bose (Sweet 1930:2695) en dat hy die Skepper is van sowel die lig as van die duisternis (Jes 45:7).

Matteus 8:12; 22:13 en 25:30 se 'diepste duisternis' ${ }^{\prime 35}$ of

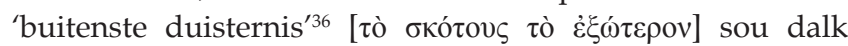
enersyds 'n sinspeling op hierdie diepste plek van die onderwêreld (Tartarus) kon wees. ${ }^{37}$ Andersyds is daar wel ook 'n baie ou tradisie wat deur Homeros gevolg was en wat Hades plaas in die sonlose streek anderkant die groot Oseanos Rivier wat die aarde omring. ${ }^{38}$ Latere tradisies verbind egter die land van die lewendes met ondergrondse grotte en riviere (Willis 1993:146). Binne die breër konteks van Matteus 8:12 is die bedoeling waarskynlik letterlik die duisternis buite die ligkring van die helder verligte saal waar die feestelikhede van die messiaanse banket plaasvind (Gundry 1982:146; Grundmann 1981:253).

\section{Duisternis as mag van die bose en die stryd om bevryding}

In die NT word duisternis dikwels gekoppel aan die bose. Hier gaan dit oor bonatuurlike en kosmiese magte. Sodoende staan lig en duisternis dan in 2 Korintiërs 6:14-15 byvoorbeeld parallel tot Christus en Belial, of Beliar (Mounce 1977:188), ${ }^{39}$ 'die waardelose een'.$^{40}$ Dis die enigste plek in die NT waar dié naam gebruik word vir Satan. Sy naam het mettertyd 'n eienaam geword in die Dooie Seerolle en in sommige van die pseudepigrafiese geskrifte. In die Dooie Seerolle kom Belial dikwels voor as leier van die magte van die duisternis (1QS 2:5; 1QM 1:1, 5, 11; 4:2; 13:2). ${ }^{41}$ Hy word beskou as 'n bose gees en 'n gees van terreur. Hy is die gees van duisternis (T. Levi 19:1; 1QM 13:12) wat beheer oor die wêreld uitoefen (1QS 1:18, 24; 2:5, 19; 1QM 14:9; Martelaarskap van Jes 2:4) en wat bose mense beheer (T. Levi ul 3:3; T. Jos. 7:4; T. Dan 1:7;

35.Vertaling van die Nuwe Afrikaanse Vertaling (1983). Die Nuwe Lewende Vertaling (2006) vertaal 'donker(te) daarbuite' - soortgelyk aan die New International Version se 'outside into the darkness' (Matt 8:12) of net 'darkness' (Matt 22:13; 25:30).

36.So vertaal deur die Ou Afrikaanse Vertaling (1933/53). So ook die King James Version ('outer darkness').

37.Philo van Alexandrië stel dit duidelik dat hulle wat dit verdien, 'afgetrek word en in Tartarus en die diep duisternis gebring word' (Philo Exesecr vi). vergelyk ook Schlatter (1963:279) oor Josefus: 'Im Hades dachte sich J.(osephus) mehr ode weniger finstere Orte.' Meeste kommentatore is van mening dat dit die 'duisternis van Gehenna' of 'die hel' is, onder andere Allen $(1985: 236)$ by $22: 13$. Davies en Allison (2004:122) by $8: 12$ en 22:13 in die jongste verkorte ICC weergawe; Grundmann (1981:470) by 22:13. Bruner (2004:383). Ook Louw en Nida (1988a:7) Grundmann (1981:47) by $8: 12$ in dink waarskynlik removed (presumably from the abode of 103:8 ('in duisternis sal julle geest ingaan') en 108:14 ('hulle wat in duisternis gebore is sal in die duisternis uitgegoo word'). Daar is wel moontlik ' $n$ sinspeling in Matteus 22:13 op die tradisie rondom Azazel wat deur die engel Raphael 'aan die hande en voete vasgebind moet word en in die duisternis gegooi moet word' (Hen 10:4-5) (Davies \& Allison 2004:371).

38. Hierdie tradisie word deur die Henogskrywer gevolg. '1 Enoch 17-36 appears to presuppose a similar image of the world to that in 1 Enoch 76-77: the habitable earth is a circular landmass surrounded by Ocean, beyond which lies a region of outer darkness and chaos' (Alexander 1992:984).

39.Vergelyk Hamilton (1992:988): 'In the Qumran literature śătān occurs only three times (1QH 4:6; 45:3; 1QSb 1:8), and never as a proper name.'

40. Hamilton (1992:988) meld dat hierdie woord ook in die OT gebruik word in verbinding met 'seun' (Deut 13:14 - Eng 13:13; 1 Sam 2:12), 'dogter' (1 Sam 1:16), 'man' (1 Sam 30:22), 'getuie' (Spr 19:28), en 'berader' (Nah 1:11).

41.Hierteenoor staan die 'heiliges' en die 'kinders van die lig': 1QS 1:9; 2:16; 11:7, 8; 1QH 11:11, 12 (O'Brien 1982:28).
T. Benj 6:1). Die wydverspreide gedagte van 'n hiërargie van engele en demoniese wesens word tot ' $n$ mindere mate in die Pauliniese literatuur aanvaar (Rom 8:38; moontlik ook 1 Kor 2:8) en tot 'n meerdere mate in die deutero-Pauliniese literatuur (Ef 1:21; 3:10; Kol 1:16;2 2:15). In hierdie korpus literatuur word die Christelike lewe verstaan as'n stryd tussen

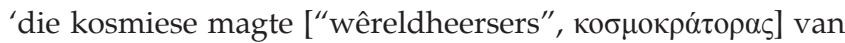
hierdie teenswoordige duisternis' (Ef 6:12; vgl. 2:2; 2 Kor 4:4) (Helyer 2000:1238-1241). Boosheid het die geestelike wêreld binnegedring en menslike lewens hierby ingesleep. Dis 'n mag wat 'n eie wil het en wat die mensdom se koers in 'n bepaalde rigting kan stuur. Die duiwel, Satan, of die prins van hierdie wêreld (Joh 12:31) se engele (Matt 25:41; 12:45), deel in sy mag. Hulle is sy instrumente wat opereer in ' $n$ sfeer van duisternis en wat op sy beurt weer lei tot 'n moreelkorrupte staat van bestaan (Bauer 1930:2626).

Uiteindelik sal Belial egter deur God se Heilige Gees vasgeketting word (T. Levi 18:12) en in die verterende vuur gewerp word (T. Jud 25:3) (Hamilton 1992:988). Ook Romeine 16:20 berig dat die God van vrede Satan binnekort sal onderwerp (vgl. ook Gen 3:15 en Ps 91:13) - 'n uitspraak wat waarskynlik gerig is op die dwaalleraars van Romeine 16:17 wat vir Satan dien. Teologies impliseer dit oorwinning oor die mag(te) van die duisternis en die immanente eskatologiese vernietiging van Satan (Bertram 1964:924). Volgens Kolossense 1:13-14 word húlle dan wat in die lig

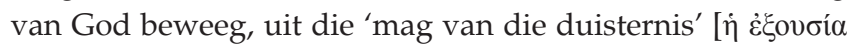

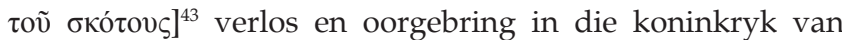
God se geliefde Seun. ${ }^{44}$ Hierdie belydenis-uitspraak versterk Christus se kosmiese almag wanneer die 'koninkryk van God se geliefde Seun' teenoor die 'mag van die duisternis' gestel word. Die Kolossense is 'oorgebring' ${ }^{\prime 4}$ na die sfeer van lig, wat in kontras staan met die tirannie waaronder hulle vroëer

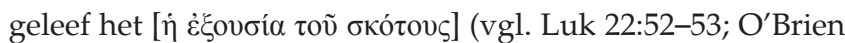
1982:27). ${ }^{46}$ Schweizer (1976) het dit passend geformuleer:

Die Welt ist als 'Macht' empfunden, und der zu V 12 aufgezeigte Sprachhintergrund zeigt, daß hier von einem Herrschaftswechsel gesprochen ist, von einer eigentlichen Umsiedlung aus einem Herrschaftsgebiet in ein anderes. Der Glaubende hat nicht nur einen von ihm frei wählbaren ethischen Entscheid getroffen; er ist von einer ihn beherrschenden Gewalt befreit worden. (p. 48)

Die Kolossense-Himne wat met die stelling van Kolossense 1:13-14 ingelui word, handel dus reeds oor die huidige

42.'While Paul (sic! GJS) clearly recognized a hierarchy of such powers (Col. 1:16, "thrones or dominions or principalities or powers"), it is not certain that he had elaborated a system of eons to serve the purposes of metaphysical theology and ethics, such as appears among the Gnostics, although they evidently believed they were developing his thought' (Heidel 1930:2455).

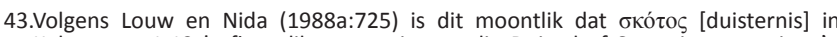
Kolossense 1:13 'n figuurlike verwysing na die Duiwel of Satan is, aangesien ह̇k

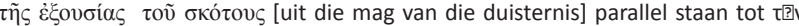
$\beta \alpha \sigma i \lambda \varepsilon i ́ \alpha$

44.Kyk ook Kolossense 2:13-15, asook Mounce (1977:188) en Sasse (1964:893).

45.Dieselfde werkwoord word in Josefus gebruik (Ant. 9.235) ten opsigte van TiglatPileser se verskuiwing van die Transjordaniese stamme na sy eie koninkryk ( $\mathrm{O}^{\prime}$ Brien 1982:27).

46.O'Brien (1982:28) sê voorts: 'This change of dominion so vividly described under the categories of "light" and "darkness" and which had taken place in the lives of
the Colossians ... at their conversion was "absolutely determinative for the life of the believer"' (vgl. 2 Kor 6:14; Ef 5:8; 1 Pet 2:9). 
kosmiese heerskappy van Christus (Kol 1:15-20). In die woorde van Duling (1992:66): 'Here, the Christians already possess citizenship in "the Kingdom of the beloved Son" in so far as they are "saints of light" who are victorious over darkness.' Die 'verlossing' waarvan hier sprake is, het reeds tot stand gekom deur die sterwe van Christus toe daar 'deur die bloed van sy kruis' en 'sy vleeslike liggaam' versoening met alles op hemel en aarde bewerk is (Kol 1:20-22). In die parallelle formulering van Kolossense 1:14, soos gevind in die uitbreiding van Efesiërs 1:7, word dit duidelik gestel dat verlossing spesifiek 'deur sy bloed' plaasgevind het tot die vergifnis van oortredings. Volgens Kolossense 1:13-14 word dit dus duidelik dat gelowiges nie net 'verlos' is van die mag van die duisternis nie, maar nou reeds 'oorgebring' is in Christus se koninkryk. Hulle het nie net reeds 'gesterf' aan die kosmiese magte wat hulle vroëer beheers het nie (Kol 2:20; 3:3), maar andersyds 'gekom tot die volheid van lewe' in Christus (Kol 2:10). Hulle is nie net saam met Christus 'begrawe' nie, maar het ook saam met Hom 'opgestaan' deur 'die geloof in die krag van God wat Hom uit die dood opgewek het' (Kol 2:12, 13, 20; 3:1). Hulle het die 'ou natuur afgelê', maar het reeds die 'nuwe natuur aangetrek' (Kol 3:9-10). Hulle toegang tot hierdie nuwe lewe het plaasgevind deur die doop, wat beskryf word as 'n 'besnydenis wat gedoen is sonder hande' (Kol 2:11-13) (Furnish 1992:1091).

Terwyl Christus en Belial teenoor mekaar geplaas word as opponerende magte in 2 Korintiërs 6:14, gaan 'mag' hier in Kolossense (en ook Hand 26:18) eerder oor die 'ruimte van die duisternis,' terwyl die 'ruimte van die lig' weer verbind word met God, met die verloste heiliges, sondevergewing en geloof in Jesus Christus, dit wil sê met die ryk van die geliefde Seun. ${ }^{47}$ Hier handel dit dan oor die Dawidiese belofte van 'n komende ryk van God se Seun (vgl. 2 Sam 7:16; Ps 2:7; 4QFlor 1:11; Luk 1:33; Schweizer 1976:48) - met LXX taal wat wil laat blyk asof dit sterk geskoei is op liturgiese en kultiese formulerings (Käsemann 1964:154-155; O’Brien 1982:25). Die sterk verbinding met die Dawidiese tradisie dui daarop dat Kolossense 1:12-14 nie eenvoudig net ' $n$ huidige ryk van die lig bedoel nie, maar ook (soos in 1 Kor 15) die domein waarin Christus regeer. Volgens Efesiërs 1:19-22 oefen God sy mag uit toe hy Christus uit die dood opgewek en in die hemel aan sy regterkant laat sit het: 'hoog bo alle bose magte en enige ander vorm van gesag waarvan daar sprake mag wees.' Hy is bo alles verhef en aangestel en alles is aan hom onderwerp. In die wêreldbeeld van die brief aan die Efesiërs word die bose se magsgebied nie net 'onder' gevind nie, maar ook 'bo'. So word die ryke verskeidenheid van God se wysheid deur die kerk bekend 'aan die bose magte in die hemelruim' (Ef 3:10) en word die lesers gemaan om die volle wapenrusting aan te trek wat God gee, aangesien hulle:

Stryd nie teen vlees en bloed is nie, maar teen die owerhede

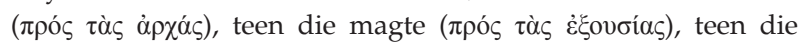

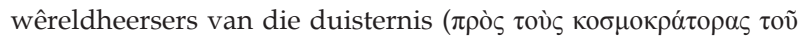

47.Vergelyk Schweizer (1976:48): "Es handelt sich also um Befreiung aus einer Versklavung zu einem Dienst, der durch das Gegenüber Gottes oder Christi und die Sündenvergebung als freiheitlicher geprägt ist, um die Versetzung ins Reich des Sohnes.'

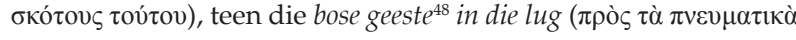

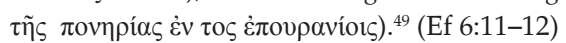

Teologies word hier dan enersyds geïmpliseer dat God se mag oor die bose ryk reeds sigbaar is in Christus wat óór en bó alles aangestel is en óór alles regeer. Andersyds word dit duidelik dat die gelowiges hulle steeds nog bevind midde-in die bose magte van hierdie sondige wêreld. Dit wil voorkom uit die Pauliniese en deutero-Pauliniese literatuur asof die gelowige se stryd teen die mag van die bose en die duisternis nou beskou word as 'n stryd wat hoofsaaklik teen 'n moreel korrupte toestand gemik is.

Die pseudepigrafiese Testament van Salomo (1ste-3de eeu nC)

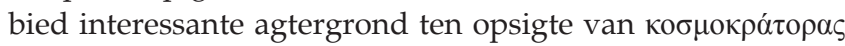

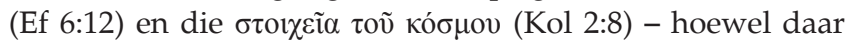
verskil van mening is oor die betekenis van $\sigma \tau о \chi \chi \varepsilon i \alpha .^{50}$ Die twee konsepte word egter met mekaar verbind in T. Sol $8: 1-4: 51$

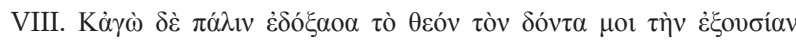

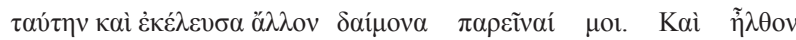

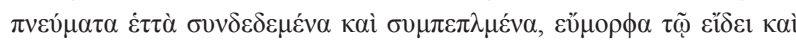

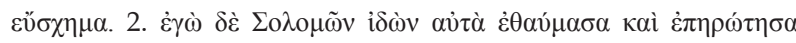

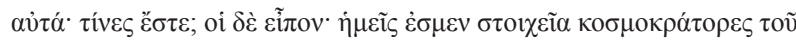

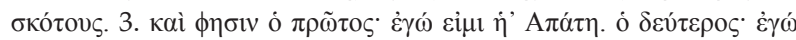

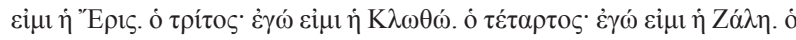

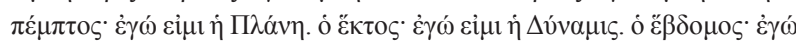

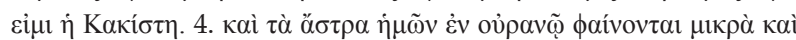

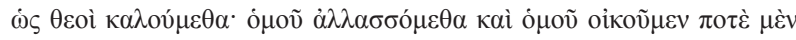

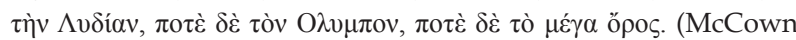
1922:31-32) [Again, I glorified God, who gave me this authority, and I commanded another demon to appear before me. There came seven spirits bound up together hand and foot, fair of form and graceful. When I, Solomon, saw them, I was amazed and asked them, 'Who are you?' They replied, 'We are heavenly

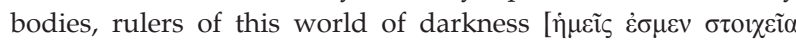

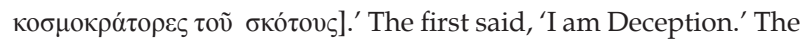
second said, 'I am Strife.' The third said, 'I am Fate.' The fourth said, 'I am Distress.' The fifth said, 'I am Error.' The sixth said, 'I

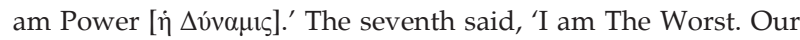

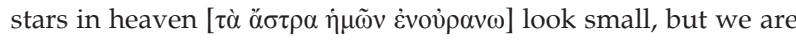
named like gods [ஸ்ऽ $\theta \varepsilon o i ̀ ~ \kappa \alpha \lambda o u ́ \mu \varepsilon \theta \alpha]$. We change our position together and we live together, sometimes in Lydia, sometimes in Olympus, sometimes on the great mountain]. (Vertaling deur Duling 1983:969-970)

Elkeen van die demone stel hulle posisie verder duideliker in die daaropvolgende konteks. So berig die sesde ('Mag'): 'I am Power. I raise up tyrants, I depose kings, and I grant power to all those who are enemies. There is an angel who thwarts me, Asteraoth' (T. Sol 8:10). In T. Sol 18:2 is die sterre

48.Thielman (2010:421) is van mening dat hierdie algemene term waarskynlik bedoel is om enige nie-menslike bose magte wat die skrywer kon oorgeslaan het, hiermee te dek.

49.'As in 2:2 where the air or "atmosphere" was the location of the devil's reign, now the "heavens" are mentioned as the seat of all powers, i.e. one region of heaven which is to be clearly distinguished from others' (Barth 1984:764).

50.Sommiges verstaan dit as persoonlike wesens, of geeste ('n interpretasie wat

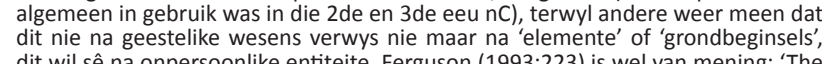
dit wil sê na onpersoonlike entiteite. Ferguson (1993:223) is wel van mening: 'The term elements (stoicheia) was applied to the heavenly bodies, a usage reflected in
several New Testament passages (Gal. 4:3, 9; Col. 2:8, 20)'.

1.C.E. Arnold, Powers of Darkness (InterVarsity Press, Downer's Grove, 1992) p. 54 So ook F. Thielman, Ephesians, p. 421: 'The Testament of Solomon may provide some insight into its meaning despite its late date and Christian redaction.' 
36 'wêreldheersers van hierdie era', terwyl daar volgens T. Sol 22:1 'geeste van dielug ( $\tau \tilde{\omega} v \pi v \varepsilon v \mu \alpha ́$ $\tau \omega v \dot{\alpha} \varepsilon \rho i ́ \omega v)$, die aarde, en onder die aarde' is. Hulle hoofdoel is die implementering van alle soorte boosheid, immoraliteit, natuurlike rampe, misvormdheid, siektes en die dood. Duling (1983:953) wys op 'n interessante (Christelike) standpunt in T. Sol 15:10: 'We (the demons) will lead astray all the inhabited world for a long time until the Son of God is stretched upon the cross.'

Vermoedelik gemik teen die praktyke van wiskundige berekenings in die astrologie met die doel om groot gebeure te projekteer en die tyd daarvan te voorspel, skryf Paulus aan die Tessalonisense dat hy nie nodig het om aan hulle te skryf oor die 'dag van die Here' nie (dit kan nie bereken word nie) want dit kom skielik, 'soos 'n dief in die nag' (1 Tess 5:1-2). Hulle word daaraan herinner dat hulle nie in die duisternis is nie, maar dat hulle almal 'kinders van die lig en kinders van

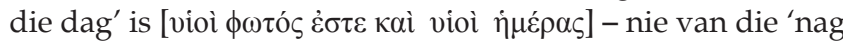

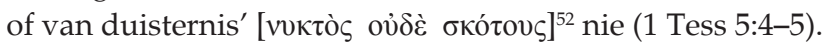

\section{Duisternis as simbool van oordeel in 'n apokaliptiese wêreld}

'n Verdere aanwending van duisternis as mag in die NT word gevind in die konteks van oordeel in 'n apokaliptiese wêreldmilieu. Die verband tussen duisternis en die element van oordeel is op te merk in gedeeltes soos Matteus 8:12 wanneer 'talle erfgename van die koninkryk in die buitenste duisternis' gewerp sal word (vgl. ook Q13:28-29; Matt 22:13) of wanneer duisternis as 'n soort apokaliptiese voorteken en simbool van God se wraak oor die sondige wêreld plaasvind tydens Jesus se sterwe (Mark 15:33; Matt 27:45; Luk 23:44) (Maier 1992:636). Die gebruik van duisternis as simbool van oordeel is algemeen in die OT, en veral in die Duodecim Prophetae. So byvoorbeeld, is 'die dag van die Here soos 'n dag van duisternis' (Amos 5:18) of is dit "n stikdonker dag, die dag van donker wolke' (Joel 2:2). Hierdie voorstelling kom weer in die 'klein Apokalips' van Markus voor wanneer kosmiese duisternis in die eindtyd toesak: 'die son sal verduister word en die maan sal nie skyn nie; die sterre sal uit die ruimte val en die kragte van die hemelruim sal ontwrig word' (Mark 13:24). Die beskrywing herinner voorts sterk aan die woorde van Jesaja 13:10: 'Die sterre en die sterrebeelde sal nie meer lig gee nie, die son sal al donker wees wanneer hy opkom, die maan sal ophou lig gee.' Die OT idee van 'n magtige persoonlike God wat betrokke is in die geskiedenis was prominent in die Judaïsme van die NT tydperk. Die Jode se hoop was dat God in die toekoms direk sal ingryp in die geskiedenis om sy oordeel uit te voer, die bose omver te gooi en verlossing te bring (Arnold 1992:444).

Duisternis word in 'n apokaliptiese wêreld nie net 'n voorteken van die bose se laaste periode nie, maar ook 'n simbool van God se oordeel oor 'n sondige wêreld. Met die aanhaling van Joël 2:28-32 in Handelinge 2:17-21 word hierdie duisternistoneel van die eindtyd geteken as ' $n$ epifanie. Dis egter veral die NT apokalips, Openbaring, wat in apokaliptiese beelde die duisternis se rol in die wêreld se kosmies-eskatologiese drama teken wanneer die finale

$52 . .$. that is, in the realm of wickedness' (Frame 1979:183). magstryd tussen lig en duisternis plaasvind. In Openbaring $8: 12$, wanneer die vierde trompet geblaas word, verloor 'n derde van die son, maan en sterre hulle lig. ${ }^{53}$ Die beskrywing in Openbaring 9:1-2 tydens die blaas van die vyfde trompet, herinner sterk aan Hades wat die sleutel dra van die Tartarus-

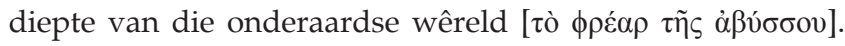
Uit hierdie 'skag' wat oopgemaak word styg nou rook op wat die son verduister en die lug laat donker word. So wend God in sy almag die duisternis van die onderwêreld aan in sy oordeel. Die magstryd tussen lig en duisternis vind egter veral plaas in Openbaring 12. Satan (Op 12:9), wat die magte van die duisternis verteenwoordig, poog om die vrou en haar kind, wat die mag van die lig verteenwoordig (son, maan en sterre, Op 12:1), te vernietig. Satan en sy duisternismag word egter afgeweer en fokus nou hulle aandag op die nakomelinge van die vrou en haar seun, dit wil sê op die volgelinge van Christus (Op 12:4-17) (Remus 1992:868). Met die uitgooi van die vyfde bak op die 'troon van die dier' in Openbaring 16:10 kom daar duisternis oor die koninkryk van die dier.

\section{Samevatting}

Duisternis blyk, net soos lig, deel van God se geskape werklikheid te wees. Afgesien van die letterlike gebruik van duisternis as die afwesigheid van lig, kom veral vier aanwendings van duisternis as simboliese werklikheid in die NT na vore. Eerstens, vanuit 'n dualistiese wêreldbeeld staan die duisternisryk as 'n opponerende mag in kontras met die ligryk van God. Daar skyn nie net moontlike trekke hiervan te vinde te wees in die Johannese vertikale dualisme nie, maar ook in aspekte van die Lukaanse teologie. Tweedens word die graf en die dood in NT literatuur in die konteks van duisternis geplaas. Die Matteusevangelie, asook 2 Petrus en Judas bevat verwysings hierna wat sterk herinner aan die onderwêreld van Hades en die diepste duisternis van Tartarus. Derdens maak die NT dit duidelik dat die duisternis die magsdomein van die bose is. Die mensdom het in die NT die keuse om in die duisternis te lewe onder die mag van die bose, om haarself besig te hou met ' $n$ immorele en doellose lewe, of om in die magsdomein van God se ryk te lewe. Die bevrydingstryd het reeds plaasgevind met die sterwe, opstanding en verhoging van Christus. Gelowiges is op hierdie wyse reeds 'oorgebring' van die een mag na die ander - soos die volksgenote van 'n oorwonne nasie deur die oorwinnende koning. Dit is veral die Pauliniese en deuteroPauliniese literatuur, met die besondere fokus van die briewe aan die Kolossense en die Efesiërs, wat hierdie aspek belig. Vierdens blyk dit in 'n apokaliptiese wêreldbeeld dat die duisternis as mag enersyds ' $n$ instrument van oordeel in die mag van God word, en andersyds die veroordeelde self is. Hierdie perspektief kom na vore in apokaliptiese gedeeltes van Matteus en Markus, maar veral in die Openbaring van Johannes.

Daar blyk dus uiteindelik twee primêre NT wêreldvoorstellings te wees oor die posisie van die duisternis as mag. Aan die een kant bevind die magsgebied van die bose ditself in die 'onderwêreld'. Mettertyd blyk hierdie

53.This absolute darkness would be far more terrifying than a partial eclipse. The scene recalls the ninth Egyptian plague with its thick darkness that spread over the land for a period of three days (Ex 10:21-23)' (Mounce 1977:188) 
magsgebied egter ook te vinde te wees in die hemelruim bokant die aarde. Die aardbewonders bevind hulleself in die magstryd tussen Belial en Christus. Maar Christus het die mag van die duisternis oorwin en is verhef hoog bokant alle magte. So breek die Nuwe Testamentiese bevrydingslig deur in 'n donker wêreld wat bedreig word deur die mag van die duisternis.

\section{Erkenning \\ Mededingende belange}

Die outeur verklaar dat hy geen finansiële of persoonlike verbintenis het met enige party wat hom nadelig kon beïnvloed in die skryf van hierdie artikel.

\section{Literatuurverwyings}

Abegg, M.G., 2000, 'War scroll (1QM) and related texts', in S.E. Porter \& C.A. Evans (eds.), Dictionary of New Testament Background, pp. 1260-1263, InterVarsity Press, Downers Grove, IL.

Alexander, P.S., 1992, 'Early Jewish geography', in D.N. Freedman (ed.), Anchor Bible Dictionary, vol. II, pp. 977-988, Zondervan, Grand Rapids, MI.

Allen, W.C., 1985, Gospel according to Matthew (ICC), T\&T Clark, Edinburgh.

Arnold, C.E., 1992, 'NT concept of power', in D.N. Freedman (ed.), The Anchor Bible Dictionary, vol. V, pp. 444-446, Zondervan, Grand Rapids, MI.

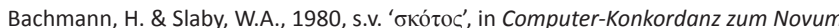
Testamentum Graece, pp. 1707-1708, Walter de Gruyter, Berlin/New York, NY.

Barrett, C.K., 2004, The Acts of the Apostles II: Acts 15-28, T \& T Clark, London. (ICC).

Barrett, C.K., 1982, 'Paradox and Dualism', in C.K. Barrett (ed.), Essays on John, pp. 98-115, SPCK, London.

Barth, M., 1984, Ephesians 4-6, Doubleday, New York, NY. (AB).

Bauckham, R., 1992, 'Hades, Hell', in D.N. Freedman (ed.), Anchor Bible Dictionary, vol. III, pp. 14-15, Zondervan, Grand Rapids, MI.

Bauer, W., 1930, 'Ruler', in J. Orr (ed.), The International Standard Bible Encyclopedia vol. IV, pp. 2625-2627, Howard-Severance, Chicago, IL.

Bautch, K.C., 2006, 'Situating the afterlife', in A.D. DeConick (ed.), Paradise Now: Essays on Early Jewish and Christian Mysticism, pp. 249-264, SBL Symposium Series 11, SBL, Atlanta, GA.

Bertram, G., 1964, S.v. ' $\sigma u v \tau \rho i ß \omega$ ', in G. Kittel \& G. Friedrich (eds.), Theological Dictionary of the New Testament (TDNT), vol. VII, pp. 919-915, Eerdmans, Grand Rapids, MI.

Bovon, F., 2002, Luke 1: A commentary on the Gospel of Luke 1:1-9:50, Fortress Press, Minneapolis, MN. (Hermeneia).

Bruner, F.D., 2004, Matthew - A commentary, vol. 1, Eerdmans, Grand Rapids, MI.

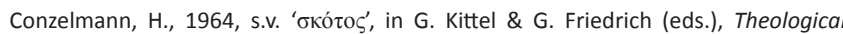
Dictionary of the New Testament (TDNT), vol. VII, pp. 423-445, Eerdmans, Grand Rapids, MI.

Davies, W.D. \& Allison, D.C., 2004, Matthew: A shorter commentary, T\&T Clark, London, New York, NY. (ICC)

Duling, D.C., 1983, 'Testament of Solomon', in J.H. Charlesworth (ed.), The Old Testament Pseudepigrapha, vol. I, pp. 935-988, Doubleday, New York, NY.

Duling, D.C., 1992, 'Kingdom of God, Kingdom of Heaven', in D.N. Freedman (ed.), Anchor Bible Dictionary, vol. IV, pp. 49-69, Zondervan, Grand Rapids, MI.

Du Rand, J.A., 1997, Johannine Perspectives, Orion, Pretoria.

Elgvin, T., 2000, 'Belial, Beriar, Devil, Satan', in S.E. Porter \& C.A. Evans (eds.), Dictionary of New Testament Background, pp. 153-157, InterVarsity Press, Downers Grove, IL.

Evans, C.A., 1992, 'Old Testament in the Gospels', in J.B. Green, S. McKnight \& I.H. Marshall (eds.), Dictionary of New Testament Background, pp. 579-590, InterVarsity Press, Downers Grove, IL.

Ferguson, E., 1993, Backgrounds of early Christianity, Eerdmans, Grand Rapids, MI.

Fitzmyer, J.A., 1981, The Gospel according to Luke $(I-I X)$, Doubleday, New York, NY. (AB)

Frame, J.E., 1979, 1 Thessalonians, T\&T Clark, Edinburgh. (ICC).

Freedman, D.N., 1992, The Anchor Bible Dictionary, Doubleday, New York, NY.

Furnish, V.P., 1992, 'Epistle to the Colossians', in D.N. Freedman (ed.), Anchor Bible Dictionary, vol. 1, pp. 1090-1096, Zondervan, Grand Rapids, MI.

Gundry, R.H., 1982, Matthew: A commentary on his literary and theological art, Eerdmans, Grand Rapids, MI.

Grant, M. \& Hazel, J. (eds.), 1979, Gods and mortals in classical mythology: A dictionary, Dorset Press, New York, NY.

Green, J.B., McKnight, S. \& Marshall, I.H. (eds.), 1992, Dictionary of Jesus and the Gospels, InterVarsity Press, Downers Grove, IL.
Grundmann, W., 1981, Das Evangelium nach Matthäus, Evangelische Verlagsanstalt, Berlin. (ThHKNT).

Hamilton, V.P., 1992, 'Satan', in D.N. Freedman (ed.), Anchor Bible Dictionary, vol. V, pp. 985-989, Zondervan, Grand Rapids, MI.

Hatina, T.R., 2000, 'Exile', in S.E. Porter \& C.A. Evans (eds.), Dictionary of New Testament Background, pp. 348-351, InterVarsity Press, Downers Grove, IL.

Heidel, W.A., 1930, 'Principality', in J. Orr (ed.), The International Standard Bible Encyclopedia, vol. IV, pp. 2454-2455, Howard-Severance, Chicago, IL.

Held, M., 1973, 'Pits and Pitfalls in Akkadian and Biblical Hebrew', Journal of the Ancient Near Eastern Society of Columbia University 5, 173-190.

Helyer, L.R., 2000, 'Tobit', in S.E. Porter \& C.A. Evans, Dictionary of New Testament Background, pp. 1238-1241, InterVarsity Press, Downers Grove, IL.

Jeremias, J., 1964, s.v. ' $\pi \dot{\lambda} \lambda \eta$ ', in G. Kittel \& G. Friedrich (eds.), Dictionary of the New Testament (TDNT), vol. VI, pp. 921-928, Eerdmans, Grand Rapids, MI.

Käsemann, E., 1964, 'A Primitive Christian Baptismal Liturgy', in E. Käsemann (ed.) Essays on New Testament Themes (SBT 41), pp. 149-168, London, SCM Press.

Kittel, G., Friedrich, G. \& Bromiley, G.W. (eds.), 1985, Theological Dictionary of the New Testament (TDNT) - Abridged in one volume, Eerdmans, Grand Rapids, MI.

Ladd, G.E., 1974, A theology of the New Testament, Eerdmans, Grand Rapids, MI.

Lewis, T.J., 1992, 'Dead, Abode of the', in D.N. Freedman (ed.), Anchor Bible Dictionary, vol. II, pp. 101-106, Zondervan, Grand Rapids, MI.

Louw, J.P. \& Nida, E.A. (eds.), 1988a, Greek-English Lexicon of the New Testament based on semantic domains, vol. I, United Bible Societies, New York, NY.

Louw, J.P. \& Nida, E.A. (eds.), 1988b, s.v. ' $\sigma \kappa o ́ \tau o \zeta^{\prime}$, in Greek-English Lexicon of the New Testament based on semantic domains, vol. II, United Bible Societies, New York, NY.

Luering, H.L.E., 1930, 'Decease in the Old Testament and Apocrypha', in J. Orr (ed.), The International Standard Bible Encyclopedia, vol. II, p. 815, Howard-Severance Company, Chicago, IL.

Maier, J.P., 1992, 'Gospel of Matthew', in D.N. Freedman (ed.), Anchor Bible Dictionary, vol. IV, pp. 622-641, Zondervan, Grand Rapids, MI.

Mallen, P., 2008, The reading and transformation of Isaiah in Luke-Acts, T\&T Clark/ Continuum, London.

Marshall, I.H., 1978, The Gospel of Luke: A commentary on the Greek Text, Paternoster Exeter/Eerdmans, Grand Rapids, MI. (NIGTC).

Martin-Achard, R., 1992, 'Resurrection (Old Testament)', in D.N. Freedman (ed.), Anchor Bible Dictionary, vol. V, pp. 680-685, Zondervan, Grand Rapids, MI.

McCown, C.H., 1922, The testament of Solomon, Hinrichs'sche Buchhandlung, Leipzig.

Metso, S., 2000, 'The Rule of the community/manual of discipline (1QS)', in S.E. Porter \& C.A. Evans (eds.). Dictionary of New Testament Background, pp. 1018-1022, $\&$ C.A. Evans (eds.), Dictionary of New
InterVarsity Press, Downers Grove, IL.

Mounce, R.H., 1977, The Book of Revelation, Eerdmans, Grand Rapids, MI.

Nickelsburg, G.W.E., 1992, 'Eschatology (Early Jewish Literature)', in D.N. Freedman (ed.), AnchorBible Dictionary, vol. II, pp. 579-594, Zondervan, Grand Rapids, MI.

O’Brien, P.T., 1982, Colossians, Philemon, Word Books, Waco, TX. (WBC 44).

Orr, J., 1930a, 'Hell', in J. Orr (ed.), The International Standard Bible Encyclopedia, vol. II, p. 1371, Howard-Severance, IL.

Orr, J., 1930b, 'Sheol', in J. Orr (ed.), The International Standard Bible Encyclopedia, vol. IV, pp. 2761-2762, Howard-Severance Company, Chicago, IL.

Osborne, G.R., 1992, 'Resurrection', in J.B. Green, S. McKnight \& I.H. Marshall (eds.), Dictionary of New Testament Background, pp. 673-688, InterVarsity Press, Downers Grove, IL.

Pesch, R., 1986, Die Apostelgeschichte. 2. Teilband. Apg 13-28, Neukirchener Verlag, Neukirchen. (EKK V/2).

Porter, S.E. \& Evans, C.A. (eds.), 2000, The Dictionary of New Testament background: A compendium of contemporary biblical scholarship, InterVarsity Press, Downers Grove, IL.

Reese, D.G., 1992, 'Demons (New Testament)', in D.N. Freedman (ed.), The Anchor BibleDictionary, vol. II, pp. 140-142, Zondervan, Grand Rapids, MI.

Remus, H.E., 1992, 'Miracle (New Testament)', in D.N. Freedman (ed.), Anchor Bible Dictionary, vol. IV, pp. 856-870, Zondervan, Grand Rapids, MI.

Rutherford, J, 1930 'Gnosticism', in J. Orr (ed.). The International Standard Bible Encyclopedia, vol. II, pp. 1240-1248, Howard-Severance Company, Chicago, IL.

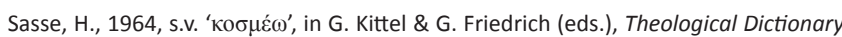
of the New Testament (TDNT), vol. III, pp. 867-898, Eerdmans, Grand Rapids, MI.

Schlatter, A., 1963, Der Evangelist Matthäus, Calwer Verlag, Stuttgart.

Schneider, G., 1982, Die Apostelgeschichte, II. Teil, Herder, Freiburg,Basel. (HThKNT).

Schweizer, E., 1976, Der Brief an die Kolosser, Neukirchener Verlag, Neukirchen.

Souli, S., 1998, Greek Mythology, Techni, Athens.

Steyn, G.J., 2008, 'Hel', in F. Gaum (ed.), Christelike Kern-Ensiklopedie, pp. 442-443, Lux Verbi.BM., Wellington.

Sweet, L.M., 1930, 'Satan', in J. Orr (ed.), The International Standard Bible Encyclopedia, vol. IV, pp. 2693-2696, Howard-Severance, Chicago, IL.

Thielman, F., 2010, Ephesians, Baker Academic, Grand Rapids, MI. (ECNT).

Van Reeth, A., 1994, Ensiklopedie van die Mitologie, Vlaeberg Uitgewers, Vlaeberg.

Vermes, G., 1987, The Dead Sea Scrolls in English, Sheffield Academic Press, Sheffield.

Williams, D.J., 1992, 'Judas Iscariot', in J.B. Green, S. McKnight \& I.H. Marshall (eds.), Dictionary of New Testament Background, pp. 406-408, InterVarsity Press, Downers Grove, IL.

Willis, R. (ed.), 1993, World Mythology, Duncan Baird Publishers, London. 